\title{
Guiding Questions Method and Extrinsic Learning Motivation of First Year University Students
}

\author{
Ermida Simanjuntak \\ Faculty of Psychology \\ Widya Mandala Catholic University Surabaya
}

\begin{abstract}
The study aimed to examine the effects of guiding questions method on university students' extrinsic motivation to study. The theory used was the ARCS model from Keller (1987) regarding extrinsic motivation to study. This study used a quasi-experimental method using a sample of 51 university students enrolled in General Psychology subject. Measurement used was an extrinsic motivation to study scale consisting of ARCS aspects which are attention, relevance, confidence, and satisfaction. Data was analysed using paired sample $t$ test and results showed that the guiding questions method was not effective to increase students' extrinsic motivation to study. However, results also showed an increase in the "satisfaction" aspect of extrinsic motivation to study following the guiding questions method.
\end{abstract}

Keywords: extrinsic motivation to study, guiding questions method, university students

Penelitian ini bertujuan untuk melihat pengaruh metode guiding questions pada motivasi belajar ekstrinsik mahasiswa. Dasar teori yang digunakan adalah model ARCS dari Keller (1987) tentang motivasi belajar ekstrinsik. Penelitian ini adalah penelitian kuasi-eksperimental dengan subjek penelitian 51 orang mahasiswa peserta mata kuliah Psikologi Umum. Alat ukur yang digunakan adalah skala motivasi belajar ekstrinsik yang terdiri atas aspek ARCS yaitu attention, relevance, confidence dan satisfaction. Data dianalisis menggunakan paired sample t-test dan hasil penelitian menunjukkan bahwa metode guiding questions belum efektif untuk meningkatkan motivasi belajar ekstrinsik pada mahasiswa. Namun, hasil penelitian juga menunjukkan adanya peningkatan aspek satisfaction dari motivasi belajar ekstrinsik subjek setelah mengikuti metode guiding questions.

Kata kunci: motivasi belajar ekstrinsik, metode guiding questions, mahasiswa

Motivation to study is a drive that pushes students to study. Some research on university students showed that motivation to study is a key factor in students' learning process in the university (Lin, McKeachie, \& Kim, 2001; Sumargi, Simanjuntak, \& Christanti, 2007; Simanjuntak, 2010; Pan \& Gauvin, 2012). Motivation to study functions to maintain students' effort in studying despite the presence of many of obstacles preventing them from studying (Elliot, Kratochwill, \& Cook, 2000; Santrock, 2006; Betoret, Artiga, \& Segura, 2014). Burden and Byrd (2010) said that motivation to study will give students' meaning to their studies so they will be willing to study and focus on their own learning goals.

Motivation to study can be classified into intrinsic and extrinsic motivation. (Elliot et al., 2000; Santrock,

Correspondence concerning this article should be addressed to Ermida Simanjuntak, Faculty of Psychology, Widya Mandala Catholic University Surabaya. Jalan Kalisari Selatan 7, Pakuwon City-Laguna, Surabaya.E-mail:mida@ukwms.ac.id
2006). Intrinsic motivation is a motivation that originates from within the individual, whereas extrinsic motivation is a motivation that comes from outside of the individual (Elliot et al., 2000; Santrock, 2006; Schunk, 2012). Intrinsic motivation is deemed to be stronger in predicting students' academic success compared to extrinsic motivation (Lin et al., 2001). From this assumption, many research on motivation to study was done focusing on the effects on intrinsic rather than extrinsic motivation (Mills \& Blankstein, 2000; Sumargi et al., 2007). On the other hand, there needed to be more research on the role of extrinsic motivation in students' learning process. Ryan and Deci (2000) stated that lecturers cannot always depend on intrinsic motivation, and thus they need to also nurture students' extrinsic motivation. Students who initially lack intrinsic motivation to absorb learning materials may become more motivated if lecturers are successful in developing extrinsic motivation. Not all subjects are innately interest- 
ing to students, and in this situation lecturers need to develop extrinsic motivation in students (Ryan \& Deci, 2000). From this explanation, more research on extrinsic motivation to study need to be done, particularly to find the best method to develop extrinsic motivation in students.

The current research is based on past studies on extrinsic motivation, showing how extrinsic motivation affects students' learning process. Sumargi et al.'s (2007) research showed that extrinsic motivation influenced students' academic achievement. Lecturers that are capable in fulfilling the elements of extrinsic motivation were found to be able to increase students' interest in learning the lecture materials. The creation of such extrinsic motivation affects students' academic achievement as shown by their grade in the subject. A survey study conducted by Simanjuntak (2010) showed that a lecturer's teaching method affected students' extrinsic motivation. Lecturers who can create interest and explain how the study materials are relevant to students' need will increase students' desire to further learn those materials. The study also showed that lecturers can create a feeling of confidence in students, making them more satisifed towards the subject (Simanjuntak, 2010). Based on these studies, it can be seen that a lecturer's given teaching method is an important component that affects students' extrinsic motivation. Therefore, a lecturer needs to consider the most appropriate teaching method that suits the students' needs to develop and maintain their motivation to study.

Studies in the Faculty of Psychology are often done using English language literature in the form of textbooks and journal articles (Sumargi et al., 2007; Simanjuntak, 2010). Most students experience difficulty with references written in English. This language difficulty has an indirect negative effect on their motivation to further process lecture materials. On the other hand, most psychology literature were written in English and lecturers cannot only rely on Indonesian-based literature. Lecturers cannot always translate English-based literature to Indonesian when teaching in class, otherwise students' ability to understand English-based literature will not improve.

Based on such condition, lecturers are expected to design a teaching method to increase students' motivation to read English-based study literature. Forsyth (2004) stated that lecturers should base students' learning process on student-centred learning to train them into becoming independent learners. Lecturers can give questions that stimulate students to think critically and to share their ideas through discussion with other students. Full-class or small group discussion are some teaching methods that can be used to stimulate students to become more active in class (Forsyth, 2004). In facilitating discussions, lecturers need to give questions that guide students to understand the literature content and aid the process of the discussion. Thus, guiding questions need to be given by the lecturer to the students.

Guiding questions method is a teaching method that involves asking questions to students to help them better understand lecture content. Traver (1998) stated that guiding questions are important components in teaching that need to be formulated well to help students understand learning materials. The use of such guiding questions in the learning process will help students to focus on the study materials (Traver, 1998). This statement is supported by McTighe and Wiggins (2013) who explained that teachers need to pose essential questions to students to help them better understand the provided study materials.

Past research on the method of guiding questions showed that these questions are useful to help students better comprehend learning materials (Lawson, Bodle, Houlette \& Haubner, 2006; Keith, Adams, Bulgren, Pouliot, \& Laraux, 2007; Lawson, Bodle \& McDonough, 2007; Bude, Wiel, Imbos, Berger, 2012). A study by Lawson et al. (2006) and Lawson et al. (2007) on psychology students showed that guiding questions can also be used on psychology-related teaching materials. Lecture materials given with guiding questions were shown to increase students' understanding of the lecture content compared to those who did not receive guiding questions (Lawson et al., 2006; Lawson et al., 2007).

Extrinsic Motivation to Study. Motivation to study is something that gives meaning to students' learning activity and will make them more willing to do learning-related tasks (McLean, 2009; Burden \& Byrd, 2010). A strong study motivation will keep students' focused on achieving learning goals. Santrock (2006) stated that extrinsic motivation is motivation that originates from outside the individual, that becomes the reason for the individual's behavior. Elliot et al. (2000) also pointed out that extrinsic motivation is a reward and an outside force that drives students to do something. Extrinsic motivation to study will be related to the role of educators as people who transfer learning materials to students and empower them in their learning process.

Keller (1987) posited a theory regarding extrinsic motivation to study called the ARCS, depicting the role of educators as people who develop extrinsic study motivation through four key elements: attention, relevance, confidence, and satisfaction. The four elements need to be fulfilled to maintain an individual's study motivation. 
Keller (1987) stated that while intrinsic motivation also affects students performance, lecturers still need to develop a systematic teaching style to maintain students' motivation. The ARCS theory is based on Tolman and Lewin's theory which stated that an individual is motivated to act if that action is double and results in valuable consequence (Keller, 1987; Sumargi et al., 2007). This theory combines values and expectations of an individual on something that becomes the creation base of motivation (Sumargi et al., 2007)

Keller (Keller, 1987; Sumargi et al., 2007) stated the following elements in the ARCS theory that need to be fulfilled in the teaching process:

(1) Attention. An educator needs to present learning materials in an interesting way to excite students to learn and explore the learning materials further. This can be done by creating cognitive surprises through presenting facts that contradict students' knowledge and experience related to the learning material. Other ways include utilising varied teaching methods, explaining through providing real examples or using humour in explanations.

(2) Relevance. Relevance is the educator's role to relate learning materials to students' needs or other important things. Students will be more interested to learn if the materials are considered useful for them. This can be done by relating the materials with students' interests, showing how the learning materials can be useful to students and relating those materials with students' future or long-term goals.

(3) Confidence. Confidence focuses on the role of educators to instil confidence in students during the learning process. When students feel like they succeeded learning, they will become more confident and consequently be more interested to further learn the materials. Some strategies that can be used by educators is designing materials with various difficulty levels, providing assessment criteria for students and helping them realise that success in study does not happen because of luck but rather due to stu-dents' own hard work.

(4) Satisfaction. Satisfaction is related to the role of educators in instilling a feeling of satisfaction in students towards their learning achievements. This can be done by praising students when they did something successfully, providing positive feedback, giving a chance for students who have already mastered a learning material to help other students who lack such mastery.

\section{Guiding Questions Method}

The guiding questions method is a teaching method that utilises questions aimed to provide guidance to a definition of a concept taught by the educator (McTighe \& Wiggins, 2013). Traver (1998) defined guiding questions as basic questions that help guide students' understanding. Guiding questions can help educators to aid students to reach the expected understanding of a concept. Guiding questions are generally used on textbooks that are aimed to help students understand the content of the textbook (McTighe \& Wiggins, 2013). Thus, guiding questions can be used by educators to help students understand the definition of a concept.

Traver (1998) explained several characteristics of guiding questions, which are open questions that help students to focus on a topic. Guiding questions do not aim to judge but rather to stimulate students' cognitive capabilities, and guiding questions are not wordy but rather will push students to give complete answers. McTighe and Wiggins (2013) described the characteristics of guiding questions as questions that aid students to explore a topic, to guide knowledge or skills that are expected to be mastered by students and to drive students to give full explanations of a certain concept. McTighe and Wiggins (2013) gave some examples of guiding questions such as "what is the definition of a balanced diet?","what are the similarities and differences of Behaviorism, Gestalt, and Freudian?", "why do composers use major and minor scales?". Such example questions help students to further read learning materials, therefore helping them better understand specific concepts.

Some researches regarding the guiding questions method showed that guiding questions can increase students' academic performance (Lawson, Bodle, Houlette, \& Haubner, 2006); Lawson, Bodle, \& McDonough, 2007; Bude, Wiel, Imbos, \& Berger, 2012). Lawson and colleagues (2006) studied university students enrolled in an introductory psychology class. Students watched a social psychology video and their understanding of the learning material was assessed through a test administered following the video. Students who watched the video and answered guiding questions had higher test scores compared to those who were not given guiding questions. Another study by Lawson et al. (2007) was conducted to examine the effects of guiding questions on university students' understanding. The researchers divided students into four groups: watching video while taking notes, watching video without taking notes, watching video while answering guiding questions, and watching video and given guiding questions but did not answer those questions. The results showed that the group that watched the video while answering guiding questions had the highest score out of all the groups. This showed that guiding questions can help students to better understand lecture materials. 
Results from both studies are in accordance with Bude et al. (2012) who found that guiding questions can increase students' understanding of a learning material. Bude et al. (2012) examined students enrolled in a statistics class, and found that students who received guiding questions aimed to help them answer test questions were shown to receive better scores compared to those who did not receive guiding questions. Guiding questions can also be used to incite discussion, according to Salter and Coneely (2015) who stated that a structured discussion will increase student participation in the learning process. The presence of guiding questions can make discussions more structured, compared to discussions with no guiding questions available to help students understand a concept.

The current research aimed to examine the effects of guiding questions on extrinsic motivation to study. The use of English-based study literature often makes students uninterested to further learn lecture materials, when it is actually very important for students to get used to reading English-based study literature. The use of guiding questions is hoped to increase extrinsic study motivation, so students will also increase their efforts to use English-based study literature. Based on the studies reviewed earlier, it was hypothesised that there is a difference in extrinsic learning motivation between before and after the implementation of the guiding questions method. The guiding questions method is hopefully able to enhance the students' external learning motivation so as to increase their understanding of the subject matter.

\section{Methods}

The current study is a quasi-experimental research using non-randomised, one group pretest-posttest design. Participants were 51 university second semester students enrolled in General Psychology II subject, consisting. 40 females and 10 males with age ranging from 18-19 years. Measurement used was the Extrinisc Study Motivation Scale by Keller and Subhiyah (1993), which was translated into Indonesian by Sumargi et al. (2007). This scale consisted of 34 items measuring four components of extrinsic study motivation: attention, relevance, confidence, and satisfaction. The scale is a Likert-type scale with five responses: strongly agree, agree, somewhat agree, somewhat disagree, and disagree.

The reliability coefficient of the extrinsic study motivation was .95 , the attention subscale was .84 , relevance was .84 , confidence was .81 , and satisfaction was .88. Some example items include: the lecturer was able to make students more enthusiastic towards the presented lecture materials (attention); the content of the lecture meets my goals and expectations (relevance); I am confident that I will get good grades in this subject (confidence); I am satisfied with this subject (satisfaction).

The procedure of the study involved the lecturer using guiding questions teaching method through using questions to guide students to better understand General Psychology materials. Students were asked to read the General Psychology written in English, and the lecturer then gave guiding questions to help students understand materials. The questions were given a week prior to the lecture so students can prepare themselves before the lecture began.

During the lecture, students were asked to answer the questions and discuss concepts in psychology as well as give real examples related to the concepts. The lecturer acted as a facilitator to guide the discussion to further aid students in understanding the psychological concepts. This procedure was done for 6 sessions during lectures in General Psychology class.

\section{Results}

Data was analysed using paired sample t-test by comparing pretest and posttest score on extrinsic study motivation scale. No significant difference was found between subject's pretest result $(M=131.02, S D=$ 16.18) and posttest result $(M=133.03, S D=10.19)$, $t(50)=.977, p>.05$. Therefore, it can be concluded that the students' extrinsic motivation did not differ

Table 1

Scores for Each Aspect of Extrinsic Study Motivation

\begin{tabular}{|c|c|c|c|c|c|c|}
\hline \multirow{2}{*}{ Aspect } & \multicolumn{2}{|c|}{ Pretest } & \multicolumn{2}{|c|}{ Posttest } & \multirow{2}{*}{$d f$} & \multirow{2}{*}{$t$} \\
\hline & Mean & $S D$ & Mean & $S D$ & & \\
\hline Attention & 30.37 & 4.28 & 30.73 & 3.43 & 50 & 0.507 \\
\hline Relevant & 30.22 & 4.04 & 30.49 & 3.28 & 50 & 0.453 \\
\hline Confidence & 38.08 & 4.88 & 37.98 & 3.58 & 50 & -0.157 \\
\hline Satisfaction & 32.35 & 5.37 & 34.04 & 3.54 & 50 & 2.578 \\
\hline
\end{tabular}


before and after receiving guiding questions.

Table 1 showed subjects' average score on pretest and posttest on each aspects of extrinsic study motivation: attention, relevance, confidence, and satisfaction. Results showed no significant difference for the aspects of attention $t(50)=.507, p>.05$, relevance, $t(50)$ $=.453, p>.05$, and confidence $t(50)=-.157, p>.05$, indicating that there was no significant difference in subject's attention, relevance, and confidence before and after receiving guiding questions. The only significant difference was found for satisfaction $t(50)$ $=2.578, p<.05$, indicating that there was a significant difference for subject's satisfaction before and after receiving guiding questions.

As additional data, the author also examined midsemester scores after receiving guiding questions method. Table 2 described mid-semester scores for subjects following the provision of guiding questions. After six sessions of guiding questions method, subjects' performance were measured based on their mid-semester scores. This score is an average of quiz results, assignment, and mid-semester exam score done by the subject. This mid-semester score is a key criteria for students to pass the subject, in addition to the final semester score obtained by students after the mid-semester exam. The score ranges from $0-100$ with a minimum passing score of $\geq 54$ (the standard passing score in the university where the study was conducted). The students' mid-semester score are as follows (Table 2).

Results from Table 2 showed that $58 \%$ of the students obtained $\mathrm{B}, \mathrm{B}+$, and A scores after receiving guiding questions method. However, around $20 \%$ of the students still failed to receive a passing grade, indicated by their $\mathrm{D}$ and $\mathrm{E}$ scores.

Results of the data analysis showed no significant difference of students' extrinsic motivation to study examined through the provision of guiding questions method. Although not statistically significant, the results showed a minor increase of average extrinsic

Table 2

Subject's Mid-Semester Score

\begin{tabular}{cccc}
\hline Score & Grade & $\begin{array}{c}\text { Number of } \\
\text { Subjects }\end{array}$ & Percentage \\
\hline $\mathrm{X} \geq 80$ & $\mathrm{~A}$ & 5 & $10 \%$ \\
$75 \leq \mathrm{X}<80$ & $\mathrm{~B}+$ & 12 & $23 \%$ \\
$66 \leq \mathrm{X}<75$ & $\mathrm{~B}$ & 13 & $25 \%$ \\
$61 \leq \mathrm{X}<66$ & $\mathrm{C}+$ & 5 & $10 \%$ \\
$55 \leq \mathrm{X}<61$ & $\mathrm{C}$ & 6 & $12 \%$ \\
$45 \leq \mathrm{X}<55$ & $\mathrm{D}$ & 8 & $16 \%$ \\
$\mathrm{X}<45$ & $\mathrm{E}$ & 2 & $4 \%$ \\
\hline Total & & 51 & $100 \%$ \\
\hline
\end{tabular}

study motivation score on posttest compared to pretest. This suggested that there was a slight increase of extrinsic study motivation score in students after receiving guiding questions method.

\section{Discussion}

Data analysis results showed that guiding questions method is not yet effective to increase university students' extrinsic study motivation. There was no significant difference in extrinsic motivation before and after students received guiding questions, particularly in the aspects of attention, relevance, and confidence.

Based on the results, guiding questions method have yet to succeed in influencing students' attention during lectures, and thus lecturers need to combine this teaching method with other methods. In addition, the use of guiding questions have not yet increased students' feeling of relevancy or usefulness of lecture materials for their lives. Guiding questions was also not found to increase students' confidence when studying the materials. The only result that differ was satisfaction, for which students felt significantly more satisfied towards the lecture following the use of guiding questions.

Keller (1987) mention that educators have an important role to nurture students' extrinsic motivation in the learning process. Educators need to fulfil the four elements of extrinsic motivation which include attention, relevance, confidence, and satisfaction. In the current study, the use of guiding questions utilised by the lecturer have yet to fulfil all four components of extrinsic motivation, which could explain the lack of significant results on students' extrinsic study motivation. One aspect, namely satisfaction, was succesfully met.

It would seem that the guiding questions presented by the lecturer were helpful enough to aid students to further understand the lecture materials, increasing students' sense of satisfaction towards their achieved academic results. This can be seen in the mid-semester score, where $58 \%$ of the students received good grades. Lawson et al. (2006) and Lawson et al. (2007) stated that guiding questions can increase students' understanding of lecture materials. Therefore, a good understanding of lecture materials will indirectly affect students' sense of satisfaction towards their study achievements.

The lack of significant results can also be explained as a consequence of students' varying English language proficiency, which was not controlled by the author. Jay (2003) mentioned that an effective reader will automatically be familiar with the reading material. 
This is the distinguishing feature between an effective and a less effective reader (Jay, 2003). For students who lack English-language proficiency, the guiding questions presented may have little to no effects to help them further understand the lecture materials. Gleason and Ratner (1998) noted that the desire to read will arise when an individual possesses sufficient knowledge to understand words used in the text. Therefore, students who do not understand English very well may not receive as much benefit from the guiding questions.

\section{Limitations and Suggestions for Future Research}

Some limitations of the study was the fact that the author was unable to control for the absence of some students during the lecture, which could have affected the final score of the extrinsic study motivation. In addition, the author did not specifically examine intrinisic motivation that may affect attention, and may indirectly influence students' extrinsic study motivation as a whole. Lastly, the measurement of extrinsic study motivation was done using self reports and thus there is a possibility that students may answer the survey based on what they thought at the present moment, and this may not reflect their general displayed behaviour.

Future research in this area would benefit from formulating the most appropriate teaching method to develop extrinsic study motivation for university students. Developing measurement tools that are not based on self reports can also be useful to measure extrinsic study motivation in more detail. Researchers also need to control other variables that could possibly affect test results such as IQ, intrinsic motivation, English language proficiency, students' study regulations and their learning style.

\section{Conclusion}

Results of the present study indicated that the use of guiding questions method is not yet effective to increase students' extrinsic study motivation. The use of guiding questions was found to increase students' satisfaction of the learning process, however it was not as effective in increasing attention, relevance, and confidence. Therefore these implications of the current study can be used to inform lecturers of the need to develop the most appropriate method of guiding questions for their own teaching purposes. Lecturers can tailor the most suitable way of presenting guiding questions according to students' English language capabilities to increase extrinsic study motivation.

\section{References}

Betoret, F.D., Artiga, A.G., \& Segura, S.L. (2014). Personal variables, motivation and avoidance learning strategies in undergraduate students. Learning and Individual Differences. Learning and Individual Differences, 35, 122-129

Bude, L., Wiel, M.W.J., Imbos, T., \& Berger, M.T.F. (2012). The effect of guiding questions on students' performance and attitude towards statistic. British Journal of Educational Psycholog, 82(2), 340-359.

Burden, P.R. \& Byrd, D.M. (2010). Methods for effective teaching: Meeting the needs of all students. London: Pearson International Edition.

Elliot, S.N., Kratochwill, T.R., Cook, J.L. (2000). Educational psychology: Effective teaching, effective learning (3rd ed.). New York: McGraw Hill.

Forsyth, D. R. (2004). The professor's guide to teaching: Psychological principles and practices. Washington, DC: American Psychological Association.

Gleason, J. B., \& Ratner, N.B. (1998). Psycholinguistics. Wadsworth City, Belmont: Thomson Wadsworth.

Jay, T.B. (2003). The psychology of language. New Jersey: Prentice Hall, Inc.

Keith, L.B., Adams, G.L., Bulgren, J.A., Pouliot, N., \& Laraux, M. (2007). Effects of curriculum maps and guiding questions on the test performance of adolescents with learning disabilities. Learning Disability Quaterly, 30(4), 235-244.

Keller, J. (1987). Development and use of the ARCS model of motivational design. Journal of Instructional Development, 10(3), 2-10.

Keller, J., \& Subhiyah, R. (1993). Manual for the course interest survey (CIS) (Developed by J.M. Keller \& R.Subhiyah.). Tallahassee, FL: Florida State University, Florida.

Lawson, T. J., Bodle, J. H., Houlette, M. A., \& Haubner, R. R., (2006). Guiding questions enhance student learning rrom educational videos. Teaching Psychology, 33(1), 31-33

Lawson, T. J., Bodle, J. H., \& McDonough, T.A., (2007). Techniques for increasing student learning from educational videos: Note versus guiding questions. Teaching Psychology, 34(2), 90-93.

Lin, Y. G., McKeachie, W.J., \& Kim, Y.C. (2001). College student intrinsic and extrinsic motivation and learning. Learning and Individual Differences, 13(3), 251-258.

McLean, A. (2009). Motivating every learner. London: Sage Publication, Ltd

McTighe, J., \& Wiggins, G. (2013). Essential questions: Opening doors to student understanding. Alexandria, 
VA: The Association for Supervision and Curriculum Development (ASCD)

Mills, J. S., \& Blankstein, K. R. (2000). Perfectionism, intrinsic vs extrinsic motivation and motivated strategies for learning: A multidimensional analysis of university students. Personality and Individual Differences, 29(6), 1191-1204.

Pan, Y., \& Gauvin, M. (2012). The continuity of college students' autonomous learning motivation and its predictors: A three-year longitudinal studies. Learning and Individual Differences, 22(1), 92-99

Ryan, R.M., \& Deci, E.L. (2000). Intrinsic and extrinsic motivations: Classic definitions and new directions. Contemporary Educational Psychology, 25(1), 54-67.

Salter, N. P., \& Conneely, M. R. (2015). Structured and unstructured discussion forums as tools for student engagement. Computers in Human Behaviour, 46 (issue C), 18-25.
Santrock, J. W. (2006). Educational psychology. New York: McGraw-Hill, Inc.

Simanjuntak, E., Sumargi, A.M., \& Apsari, Y. (2004). Metode pengajaran dengan menggunakan miling list untuk meningkatkan motivasi belajar mahasiswa. Anima Indonesian Psychological Journal, 19(2), 167-178

Simanjuntak, E. (2010). Motivasi belajar ekstrinsik pada mahasiswa Fakultas Psikologi Unika Widya Mandala Surabaya (Unpublished research report). Faculty of Psychology, Unika Widya Mandala Surabaya

Sumargi, A.M., Simanjuntak, E., Christanti, F.D (2007). Analisis motivasi belajar ekstrinsik dan pengaruhnya terhadap prestasi belajar mahasiswa. Insan Media Psikologi. 9(3), 199-214.

Traver, R. (1998). What is a good guiding question? Educational Leadership. 55(6),70-73. 